\title{
Experience of Doing Independent Care for Covid-19 Suspect Client With Chronic Obstructive Pulmonary Disease (COPD) Comorbid
}

\author{
Afif A Amrullah*, Cahya Arbitera) ${ }^{1}$ \\ Public Health, Universitas Pembangunan Nasional Veteran Jakarta \\ Corresponding email: afifkesmask3@gmail.com
}

\begin{abstract}
Background: Corona infection is a viral infection that attacks the respiratory system. Patients who are classified as suspect Covid-19 undergo independent isolation at home or in the hospital so that they do not transmit to other people and their health conditions are monitored. Home care of patients with suspected Covid-19 with comorbids such as COPD must be carried out carefully by looking at indicators of respiratory function, such as cough frequency and sputum (number, color). This is because respiratory problems in Covid-19 patients indicate damage to the condition and can lead to death. Method: The study design was a case report. The purpose of making this case report is to describe the home care process for suspected Covid-19 patients with comorbid COPD. Case description: A female client, 50 years old, has a Covid-19 infection, namely, dry cough, runny nose, lost smell, diarrhea with PCR + test, who has a COPD comorbid with thick, cloudy sputum and is difficult to remove and undergoes isolation at home. Treatment emphasizes increasing immunity through nutritional support, herbs, rest, antibiotics / symptom medications and stress management. The client shows an improvement in health status after undergoing 7 days of home treatment. Conclusion: Treatment of the client suspect Covid-19 with comorbid COPD can be done at home with quick results
\end{abstract}

Keywords: COVID-19, comorbid COPD, sputum, home care

\section{INTRODUCTION}

Corona infection has spread throughout Indonesia, especially big cities like Jakarta. Based on data from the DKI Jakarta Provincial Health Office on September 13, 2020 , there was an increase in positive cases were obtained as many as 54,864 cases ( 389 cases were data on cases outside the Jakarta area in the last 7 days, resulting in a reduction in total positive case data). Of the total number of cases, 41,014 people were declared recover with a recovered rate of $74.8 \%$, and a total of 1,410 people died with a death rate of $2.6 \%$, while Indonesia's death rate was $4.1 \%$. Based on the flow of action provided by the Ministry of Health of the Republic of Indonesia, through the Decree of the Minister of Health Number HK.01.07 / Menkes / 413/2020 concerning Guidelines for the Prevention and Control of Coronavirus Disease 2019 (Covid-19) signed on July 13, 2020; The categorization of patients related to Covid infection is the suspected, confirmed and close contact group.

Patients Under Supervision (PDP) 1. People with Acute Respiratory Infection (ARI), namely fever $(\geq 38$ oC) or a history of fever; accompanied by any of the symptoms / signs of respiratory disease such as: cough / shortness of breath / sore throat / runny nose / pneumonia from mild to severe AND in the last 14 days comliving in a country / region that reports local transmission; 2. People with fever $(\geq 38 \mathrm{oC})$ or a history of fever or ARI AND in the last 14 days before symptoms develop have a history of contact with confirmed or probable cases of COVID-19; 3. People with severe ARI / severe pneumonia *** requiring hospitalization AND no other cause based on a convincing clinical picture. 
A suspect case is a new definition that replaces the term PDP. That is, a suspected case (formerly known as PDP) is a person who has one of the following criteria: - People with acute respiratory tract infection (ISPA) and in the last 14 days before symptoms appear have a history of travel or live in a country / region of Indonesia where local spread is recorded.

- People with one of the symptoms / signs of ARI and in the last 14 days before symptoms develop had a history of contact with a confirmed / probable Covid19 case.

- People with severe ARI / severe pneumonia requiring hospitalization and no other cause based on a convincing clinical picture.

\section{CASE REPORT}

Complaints of the first day (Morning):Mrs. A's client, 50 years old complained of headache; body aches and muscle aches; cough with little phlegm, clear, difficult to expel; runny nose, dry throat and fever. loss of appetite, diarrhea and complaining of stomach pain. Smell is still functioning well. Medical history the day before the client returned from the city of Kuningan (300 km east of Jakarta). And there are no complaints, the disease she suffers from COPD, checked in the morning temperature in axilla 37.9 (in an air-conditioned room) but the client feels fever and chills; breathing $26 \mathrm{x} /$ minute, shallow, didn't feel tightness and chest pain. Pulse 80x / minute; BP:110/78 mm Hg, TB: $163 \mathrm{BW:}$ $49 \mathrm{~kg}$. The client did not suspect that she had Covid -19 , the client assumed it was due to fatigue and lack of sleep after traveling out of town. Anicteric sclera and no conjunctivitis; 3 consecutive days before the client had contact with a colleague who was confirmed with Covid19 (PCR +), who when complaints started to arise, he was undergoing treatment at Duren Sawit Hospital.

Actions on the first day: eat 3 times a day; intake traditional herb medicines ( jamu ) contains ginger with turmeric plus sugar 4-5 times x $300 \mathrm{ml}$ a day aims to reduce bloating, diarrhea, fatigue and endurance; paracetamol 3x500 mg to reduce heat; vitamin B6 2x30 $\mathrm{mg}$ to reduce fatigue; ranitidine $1 \times 150$ for relieving stomach upset; Acetyl cysteine $2 \times 200 \mathrm{mg}$ as an expectorant; suck on eucalyptus oil to feel refreshed and relieved og breath. Client total bedrest; basic need as like grooming with partial assisted. Evaluation (afternoon): eat an average of 4-5 tablespoons of rice / each meal; herbal medicine 4 x200 ml / day; Defecate with liquid stool 5-6 times and abdominal pain + ,; feeling tired and lack of sleep. Dry phlegm that difficult to remove; temperature 38.0-38.2 C. On the second day, Complaints: same like first day, the smell begins to decrease, but the tongue still tastes bitter of eucalyptus oil. Action: be continued, multivitamin high dose vit $\mathrm{C}\left(\right.$ Selkom $\left.^{\mathrm{R}}\right)$ Result: sputum + , thick white color., Temperature: fluctuate $37.8-38.2 \mathrm{C}$ especially after being given paracetamol, runny nose +
On the third day, Complaints: Temperature $38.1 \mathrm{C}$; client looks like sleeping, but feels less / not soundly;, phlegm + , cloudy yellow, thick, complaints of tightness-; feel tired; appetite -; bowel times a day; the smell and taste on the tongue of eucalyptus oil is gone, the family is worried about happy hypoxia [1]. Action: be continued, traditional herb medicines 2 glasses of kencur and lemongrass to increase sputum secretion, saffron flower immersion drink $500 \mathrm{ml} /$ day; Cotrimoxazole forte 2x960 mg; multivitamin highdose vitamin C (selkom $^{\mathrm{R}}$ ) 2x1 tablet; SWAB Test.

Evaluation: all measures were carried out, temperature 38.1-38.3 C; the family began to worry, especially associated with cloudy phlegm, there was no tightness Fortfh-fifth day, Complaints: be continued, the result of the swab test was positive; advice from office leaders and officers to be treated in the hospital; lack of sleep; sputum easily issued a cloudy yellow color. Action: implementation of self-isolation because the client refuses to be taken to the Emergency Hospital. Therapy is continued. Evaluation: the client decides to refuse to be hospitalized because it will cause more stress; complaints of tightness, etc. do not exist. On the sixth day, Complaints: Morning body temperature 37.6, cough + ; sputum +++ , thick yellow and slightly cloudy; out of breath -; sleepy; skin area of the lips begins to mark peeling; colds - Action: Jamu passed on; drugs: cotrimoxazole, vitamin B6; theres is no change for the drugs like the day before except Parsetamol and selkom stopped. Results: The client seemed calm, the intake of herbs and food had not changed; phlegm begins to whitish yellow, easy to remove.

On the seventh day, Complaints: felt fever, temperature $37,8 \mathrm{C}$; the skin around the mouth, the face peels off. Occasionally cough, white, watery sputum. Action: other same /be continued : the dose of ginger in herbal medicine increased; paracetamol

$2 \times 500 \mathrm{mg}$, cotrimoxazole $2 \times 960 \mathrm{mg}$, acetylsistein 2x200 mg Evaluation: at $16.00 \mathrm{WIB}$, the client felt no more fever; temperature $37.4 \mathrm{C}$. Eighth-fourteenth day, Complaints: occasional cough (1-2 x/hour), temperature 36.7-37.3 C; feel better, still feel weak, the skin around the mouth peels more and more, the drug is continued; the saffron flower immersion stopped; morning menu after morning ( subuh ) prayers is eating sweet mang fruit aim to increase appetite. Evaluation: increase in calorie consumption to 70-100 gr / meal; don't feel feverish; white-clear, watery sputum is easily excreted; the tongue start can taste.

\section{DISCUSSION}

Patients under surveillance (PDP) or suspected according to the criteria of the Indonesian government are 1) People with acute respiratory infections (ARI), namely fever ( $\geq 38 \mathrm{C}$ ) or a history of fever; accompanied by any of the symptoms / signs of respiratory disease such as: cough / shortness of breath 
/ sore throat / runny nose / pneumonia from mild to severe \# AND there is no other cause based on a convincing clinical picture AND in the last 14 days before symptoms appear have a history of travel or living in the country / region reporting local transmissions *.

2) People with fever ( $\geq 380 \mathrm{C}$ ) or history of fever or ARI AND in the last 14 days before symptoms develop have a history of contact with a confirmed case of COVID-19. 3) People with severe ARI / severe pneumonia ** requiring hospitalization AND no other cause based on a convincing clinical picture.

Based on these criteria the client is included in the PDP or suspected category because she has a body temperature of $38 \mathrm{C}$, has a history of exposure to people with confirmed COVID-19, trips out of the region and crowds (gas stations during the trip) and has a comorbid form of COPD, and can be categorized as moderate degrees for the disease.

Actions on PDP or moderate degree of suspicion according to the criteria of the Indonesian government and DKI Jakarta are by being referred to an emergency hospital that has been appointed. Kramat Jati or RSUD Duren Sawit., In order to monitor the development and anticipation of the client's worsening condition. However, here the client and family refuse on the grounds that the new atmosphere will cause new stress and can affect the client's healing process.

The principle of the client and family in treatment is to fight the virus by increasing immunity through reducing stressors and increasing immunomodulators. This was proven by the client who experienced a reduction in symptoms on the 6th day of treatment, particularly in relation to the improvement of respiratory conditions, namely the cough with phlegm, which was originally a cloudy yellow color, gradually became brighter. The color of sputum is known to indicate a person's disease condition [2], a cloudy yellow color indicates a suppurative infection process. the presence of pulmonary infection will inhibit oxygen exchange which in turn will reduce the immunity of the client. It is known that the problem of respiratory problems is a weighting factor for sufferers of Covid-19 [1]. Judging from the curve, the humoral immune response, improved on day 6 , proves that the body's immune response is fast active, or one day faster than the curve, which will start to be active on day 7 . Based on the immunological curve of Covid-19 sufferers, [3] on the 6th day, replication was still found, and antigen levels were still high. Decreased fever, improved sputum discoloration and improved recovery symptoms.

Efforts to reduce stressors carried out by families are by doing treatment at home so that clients feel familiar. Home treatment makes it easy for patients to be free to do activities such as eating, sleeping, without being disturbed by officers, and this is positive for increasing the meaning of immunity [4]. Allowing clients to rest without having to follow a schedule of environmental activities is also important, this is different from in a hospital, the patient's activities are determined by the activities of the officer or the room. For example, a patient is taking a break, being awakened by a nurse because a routine check will be carried out, so that the patient feels less sleep, and lack of sleep can cause stress which will affect the body's immunity.

The second factor that is thought to play a role in accelerating recovery is the consumption of Traditional and Complementary Alternative Medicines such as turmeric, ginger, coriander, lemongrass and kencur. It is known that these herbs containing curcumin and antioxidants that take an effect on immunity. Research shows curcumin is able to bind to the SARS-CoV 2 protein receptor by binding to the protease domain (6Lu7) and glycoprotein spikes. This bond has the potential to inhibit the activity of Covid-19 [5]. Kencur and lemongrass are known to have expectorant and bronchodilator effects. curcumin is known to inhibit the release of inflammation-causing body compounds or pro-inflammatory cytokines such as interleukin-1, interleukin- 6 and tumor necrosis factor- $\alpha$. Cytokines are known to be substances that can cause tightness in the respiratory tract [6]. Curcumin also has the effect of inhibiting the virus growth process, either directly by physically damaging the virus or by suppressing cellular signaling pathways that are important in the viral replication process [7]. Consumption of ginger is known to increase cell phagocytosis and immunomodulatory [8]. The third factor that is thought to speed up recovery is the consumption of high doses of vitamin $\mathrm{C}$, zinc and vitamin $\mathrm{E}$. It is known that vitamin $\mathrm{C}$ is an important micronutrient for humans, with pleiotropic function related to its ability to donate electrons [9], while vitamin $\mathrm{E}$ is an immunomodulator in the body's immune cells [10]. The fast client healing may also be affected by zinc consumption. It is known that zinc can activate the thymus as a site for differentiation and $\mathrm{T}$ cell maturase regulates the release of cytokines by peripheral mononuclear cells in the blood, stimulates the formation of CD8 $\mathrm{T}$ cells, along with interleukin 2 (IL-2), and maintains receptor activity for IL-2 on T cells mature [11].

\section{CONCLUSION}

Treatment of patients under surveillance (PDP) or suspect COVID-19 with comorbid COPD and categorized as moderate at home, in fact can experience

faster symptom improvement, namely on the 6th day. The speed of this improvement is obtained through increasing immunity through reducing stressors and activating the system.:immunomodulators with herb (jamu) and multivitamin.

\section{REFERENCES}

[1] Kemenkes RI, "Pedoman Penanganan Cepat Medis dan Kesehatan Masyarakat COVID-19 di Indonesia," 2020. Silvia, "Kriteria Warna Dahak," 2011. 
http://repository.unimus.ac.id/1873/4/12. BAB II.pdf (accessed Sep. 20, 2020).

[3] T. D. Ardyanto, "Si Covid-19 Dan Tubuh Kita," Solopos, 2020. https://www.solopos.com/si-covid19-dan- tubuh-kita-1057008.

[4] Z. Farhan, "Prediktor Stres Keluarga Akibat Anggota Keluarganya Dirawat di General Intensive Care Unit," vol. 46, no. 3, pp. 150-154, 2014.

[5] Humas Litbangkes, "Curcumin, Aman Dikonsumsi Saat Pandemi Covid-19," Badan Litbangkes Kemenkes RI, 2020.

[6] P. P. Sordillo and L. Helson, "Curcumin suppression of cytokine release and cytokine storm. A potential therapy for patients with Ebola and other severe viral infections," In Vivo (Brooklyn)., vol. 29, no. 1, pp. 1-4, 2015.

[7] D. Mathew and W.-L. Hsu, "Antiviral potential of curcumin,” J. Funct. Foods, vol. 40, pp. 692-699, 2018 ,

doi: https://doi.org/10.1016/j.jff.2017.12.017.

[8] Z. G. Saputri, “Optimalisasi pemanfaatan Jahe sebagai minuman Kesehatan,”.Jurnal Pemberdaya. Publ. Has. Pengabdi. Kpd. Masy., vol. 2, no. 2, 2018, doi: https://doi.org/10.12928/jp.v2i2.383.

[9] A. Carr and S. Maggini, "Vitamin C and Immune Function," Nutrients, vol. 9, no. 11, p. 1211, 2017, doi: 10.3390/nu9111211.

[10] G. Y. Lee and S. N. Han, "The Role of Vitamin E in Immunity," Nutrients, vol. 10, no. 11, 2018, doi: 10.3390/nu10111614.

[11] F. Yan, X. Mo, J. Liu, S. Ye, X. Zeng, and D. Chen, "Thymic function in the regulation of T cells, and molecular mechanisms underlying the modulation of cytokines and stress signaling (Review)," Mol Med Rep, vol. 16, no. 5, pp. 7174-7184, 2017, doi: 10.3892/mmr.2017.7525. 